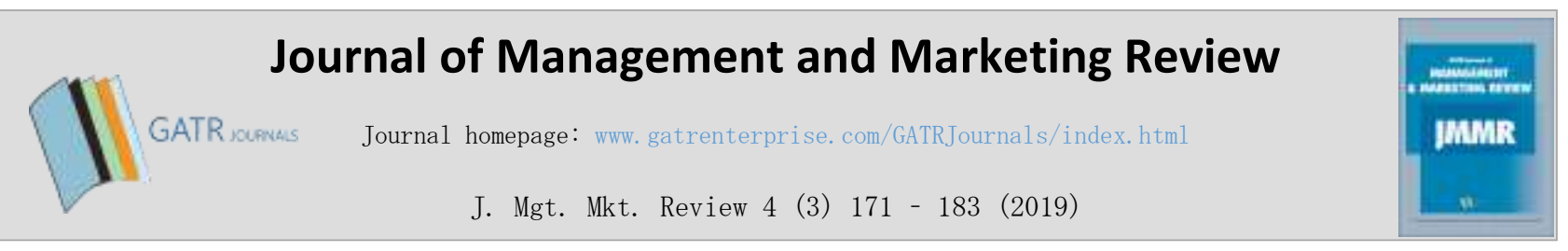

\title{
The Influence of User Generated Content and Purchase Intention on Beauty Products
}

\author{
Firda Nosita ${ }^{1}$, Tina Lestari ${ }^{2}$ \\ ${ }^{1}$ Department of Management, Sekolah Tinggi Ilmu Ekonomi Pancasetia, Jl. A. Yani KM. 5,5, 70248, Banjarmasin, Indonesia \\ ${ }^{2}$ Department of Accounting, Sekolah Tinggi Ilmu Ekonomi Pancasetia, Jl. A. Yani KM. 5,5, 70248, Banjarmasin, Indonesia
}

\begin{abstract}
Objective - The thrive of social media enables everyone to share their purchase and consumption experiences, including beauty product consumption. The study aims to determine whether the attitude towards UGC, perceived credibility and user activity of UGC on YouTube influences the purchase intention toward a beauty product.

Methodology/Technique - Questionnaires were distributed online to 200 people who had watched beauty product review videos on YouTube at least once and who were minimum 18 years old. The data was analyzed using multiple regression.

Findings - The results indicate that attitudes towards UGC content on YouTube and perceived credibility affect purchasing intentions. Whereas user activities does not correlate with purchase intentions on beauty products. UGC content usually provides information and provides tips and tricks about using beauty products. The more attractive the content is, the more people want to see it and the more likely they will be to use the content to fulfill their information needs. Beauty vloggers are considered more credible than producer-generated content. Activities such as searching for, liking, subscribing or commenting does not necessarily indicate purchase intentions. This simply represents people fulfilling their social needs to interact with each other in a social environment.

Novelty - Companies could provide training or facilities for UGC creators in order to create more attractive content. The most important finding of this study is that companies should continually improve the quality of their products, because the credibility of content makers relies on their experience with the products themselves. Marketers should monitor community discussions to find out more about the public interest in their products. In addition, marketers can also identify the shortcomings of their products to better enable them to fix them by reviewing comments on UGC.

Type of Paper: Empirical.
\end{abstract}

Keywords: User Generated Content (UGC); Beauty Vlogger; Beauty Product; E-WoM; YouTube.

Reference to this paper should be made as follows: Nosita, F.; Lestari,T. (2019). The Influence of User Generated Content and Purchase Intention on Beauty Products, J. Mgt. Mkt. Review, 4 (3) $171-183$.

https://doi.org/10.35609/jmmr.2019.4.3(2)

JEL Classification: M31, M37, M39.

\section{Introduction}

Euromonitor International predicts that Indonesia and Vietnam will become the fastest growing cosmetics markets in the Asian region.

\footnotetext{
* Paper Info: Revised: June 11, 2019

Accepted: September 28, 2019

* Corresponding author: Firda Nosita

E-mail: firda.nosita@gmail.com

Affiliation: Department of Management, Sekolah Tinggi Ilmu Ekonomi Pancasetia, Indonesia
} 
Indonesia is predicted to become one of the top 10 global beauty and skincare product markets in 2019 (Chrisbiyanto, 2017). With a very large population, Indonesia is believed to be a potential market share for beauty products, supported by a female population of approximately 126.8 million. YouGov (2016) found that Thai and Indonesian people use cosmetics the most, with more than half of Indonesian women (52\%) using cosmetics everyday compared to women in Australia (27\%), Singapore (27\%) and Hong Kong (28\%).

The process of purchasing decisions involves several stages, starting from problem recognition to postpurchase behavior. Market research must be conducted by product developers. With the vast range of information available, it is easier for potential customers to evaluate new products. People who have consumed goods or services can provide an assessment of those products and share their experiences with others; this process is commonly known as Word-of-Mouth (WoM). The cosmetic industry, involving products related to skincare, decorative, hair care and perfumeries, is one of the so called "try before you buy" industries as it is hampered by the consumer's need to experience the product in store by touching, feeling and smelling it before they purchase the product (Hagander \& Runarsdottir, 2016).

Electronic Word-of-Mouth (E-WOM) is defined as the positive and negative statements made by potential consumers, actual or ex-consumers about a product or a company, which are available to many people through the internet (Hennig-Thurau et. al., 2004). User Generated Content (UGC), also known as E-WOM, works like normal Word of Mouth, but is spread through online media platforms. By definition, UGC refers to a number of self-made material uploaded to the internet by non-media and has a major influence on one's consumption (Cheong \& Morrison; Dijck; Jonas, Krishnamurthy and Dou; Presi et. al. in Bahtar \& Muda, 2016) where content is generally shared on social media such as Facebook, YouTube, Twitter and Instagram. Nowadays, with millions of video makers and millions of consumers, UGC is reshaping the way people watch videos and television.

The internet has become an inseparable part of human life; internet usage is often related to economic activities, politics, social interactions and others. The number of internet users is predicted to continue to grow over the next few years. In Indonesia, the number of internet users have increased rapidly in the last 20 years. Interestingly, the number of internet users in Indonesia has now reached 54.68\% of the total population (APJII, 2017).

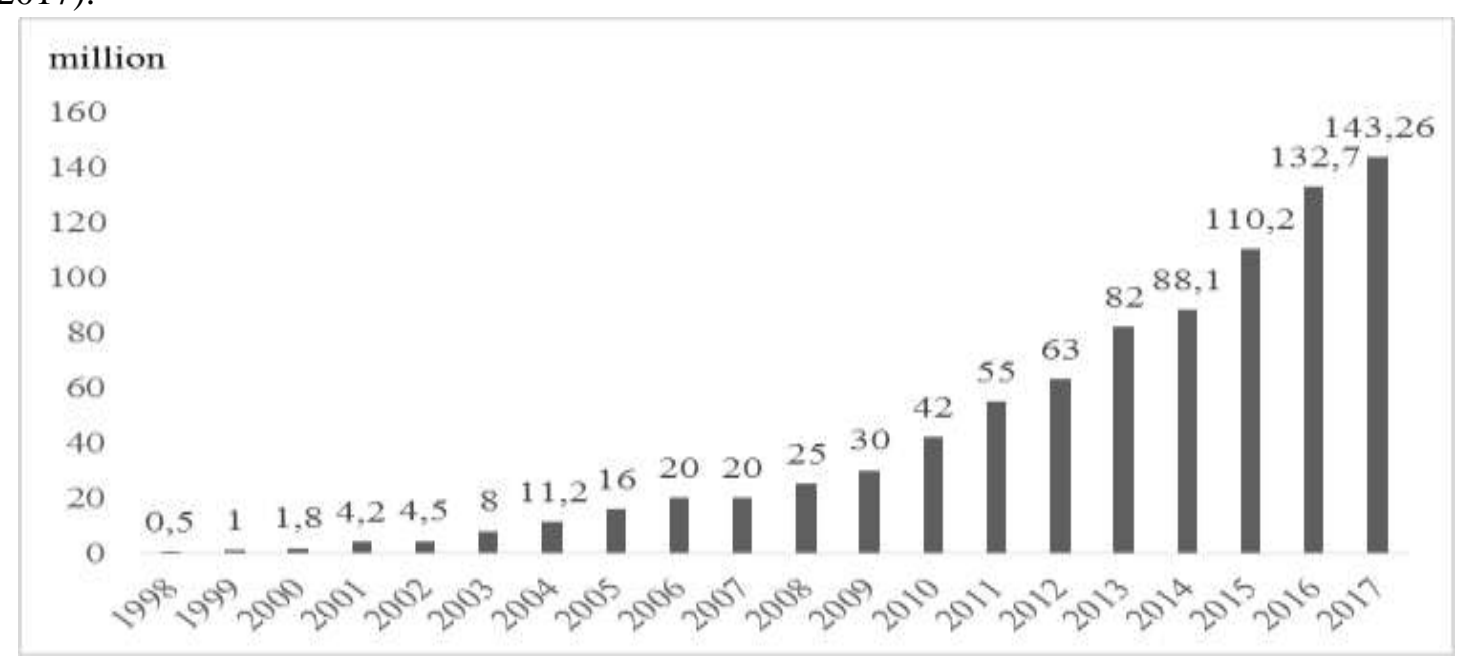

Figure 1. Indonesia's internet users growth

Figure 1 shows that almost 144 milion people have accessed the internet, with a majority of users aged between 19 to 34 years old (49.52\%). Based on an APJII survey conducted in 2017, the average time accessing the internet per individual is 1 to 3 hours per day. The most common services accessed by internet users are shown in Figure 2 below. 


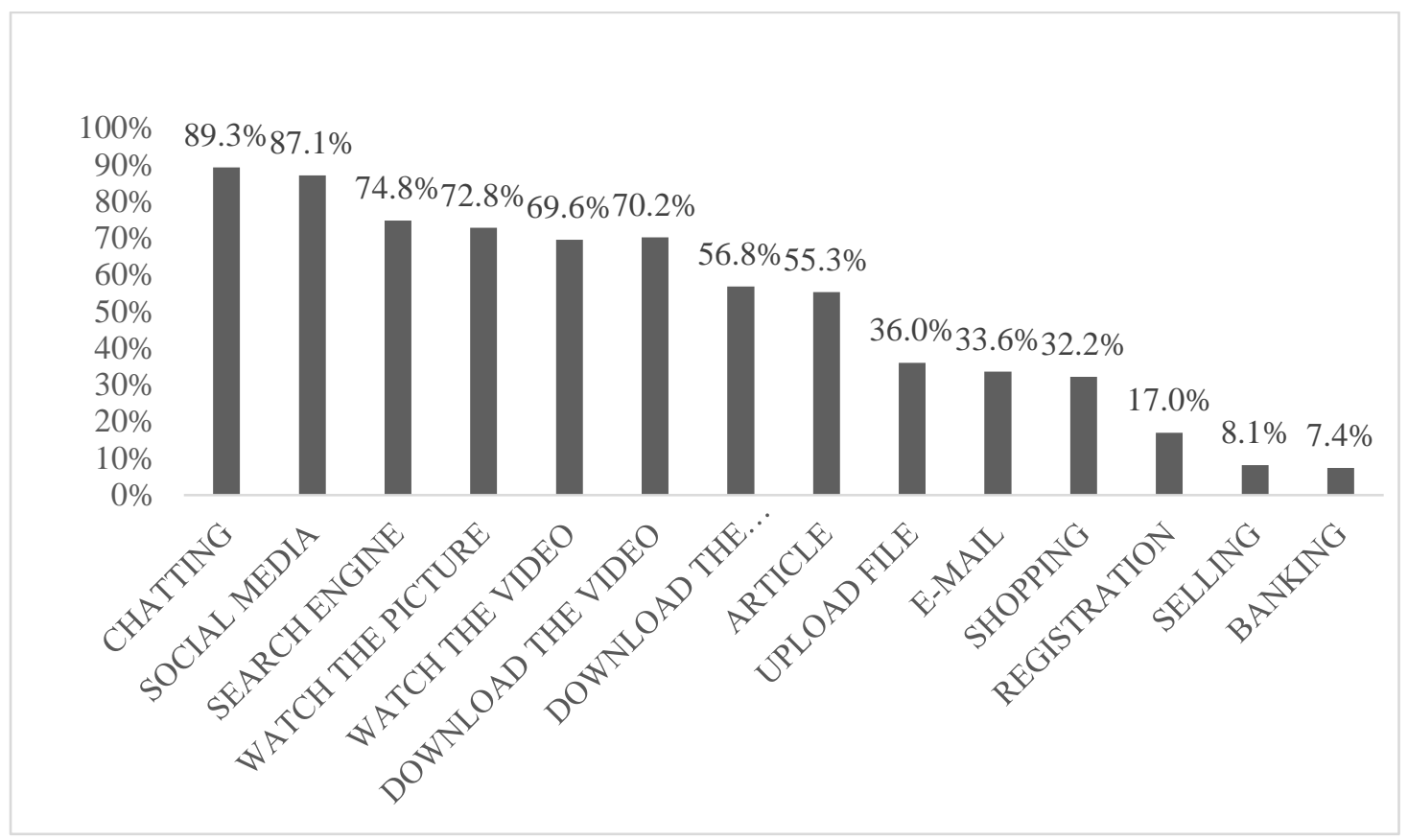

Figure 2. Services accessed by Indonesia's internet users

Figure 2 demonstrates that the most commonly used services by Indonesian people is chatting, followed by social media, search engines, watching the picture, and watching and downloading videos. The average daily time spent using the internet via any device is 8 hours, 36 minutes, whilst the average daily TV viewing time (broadcast, streaming and video on demand) is 2 hours, 52 minutes. YouTube is the most active social media platform in Indonesia, followed by Whatsapp and other social media sites.

YouTube was introduced in 2005 and became the second most visited social media site in the world in 2019 (We Are Social \& Hootsuite, 2019). YouTube allows someone to share experiences by audio-visual methods and allows their viewers to like videos, subscribe and leave comments and enables the creators to take advantage of advertising attached to the videos. YouTube presents more vivid videos and detailed information in narrative form. Millennial users prefer YouTube up to twice as much as television, men mostly watch football games or strategy games on YouTube whilst most women watch beauty videos. Table 1 shows that YouTube and detik.com are the most commonly visited sites in Indonesia on a daily basis.

Table 1. Alexa's Top Websites by the Number of Visitors and Total Page Views in Indonesia

\begin{tabular}{cc}
\hline Website & Time / Day \\
\hline YouTube.com & $08 \mathrm{M} 47 \mathrm{~S}$ \\
Detik.com & $08 \mathrm{M} 47 \mathrm{~S}$ \\
Google.com & $07 \mathrm{M} 42 \mathrm{~S}$ \\
Tribunnews.com & $05 \mathrm{M} 21 \mathrm{~S}$ \\
Bukalapak.com & $04 \mathrm{M}$ 59S \\
\hline
\end{tabular}

Source: datareportal.com, 2019

Bae and Lee (2011) found that consumers are more influenced by a consumer review of products that require experience (product experience) compared to non-experienced products. In addition, they also found that reviews from the online community were considered more credible than reviews from the seller's website. Consumers may feel that the review site provided by the seller provides product information that is biased because it is related to the seller's purpose. Johnson and Kaye (2004) suggest that weblogs are more credible than other online sources, such as newspapers, online radio news and television news. This study 
aims to determine whether Attitude, Perception of Credibility and User Activity UGC on YouTube has an effect on the Interest in Buying Beauty Products.

Videos may be entertaining or educational, focusing on a special topic related to the product or service. This content can be in the form of tutorials, testimonials, presentations, vlogs, experience, etc. Consumers use video for product demonstrations and product reviews when making purchase decisions. It has been predicted that $64 \%$ of consumers are more likely to buy a product after watching a video about it (Milhinhos, 2015). The digital consumer actively searches for unbiased information, opinions and feedback from online sources such as consumer reviews on review colomn or videos.

The rest of this paper is organized as follows. A literature review and hypothesis development are provided in Section 2. Section 3 describes the sample, data collection and analysis. Section 4 provides the results and discussion and Section 5 concludes the paper.

\section{Related Literature and Hypothesis Development}

\subsection{Electronic Word of Mouth (E-WOM) and User Generated Content (UGC)}

In today's technology driven world, social networking sites have become an avenue whereby retailers can extend their marketing campaigns to a wider range of customers (Paquette, 2013). Companies easily campaign their products through social media to a broader category of viewers and at all times of the day. The evolving media environment and new technological innovations have redefined the media environment and the role of advertising in new media consumption. Technology allows everyone to increase his/her control over media exposure. Consumers have greater control over purchasing behavior purely by virtue of the fact that they are able to share information quickly and, in most cases, around the world. The relevance of a video is dependent on the audience that it is trying to reach and the actual quality and content of the video it is not an apporpriate medium for all targets (Milhinhos, 2015).

Online consumer reviews or Electronic word-of-mouth (E-WOM) is defined as "positive and negative statements made by potential consumers, actual or former consumers about a product or company, which are available to many people via the internet (Hennig-Thurau, et. al., 2004). User Generated Content (UGC) refers to media content produced by the wider community that have experience with products, nonprofessional people paid by the company, and is usually distributed online (Daugherty, et. al., 2008). Videos uploaded by consumers are referred to as UGC and recorded videos that are shared with other users are called E-WOM.

The Interactive Advertising Bureau of the United States of America defines UGC as "the material that is made and uploaded to the internet by non-media professionals" (Christodoulides, 2012). Non-media professionals are described as creators that create UGC, as traditional media can (and often do) use their expertise and tools to make UGC as consumers, who are not part of the employees paid by the company. This is in contrast to Producer-Generated Content (PGC) which typically involves the use of celebrities to convey the benefits of a product (Verhellen, et. al., 2013). Consumers have changed and they now consider UGC to be more credible (reliable) than PGC.

User generated content refers to information and material that is produced and posted by internet users. In fact, consumer reviews are more relevant than expert reviews; people will write positive or negative reviews depending on the phsycological incentive. Consumers may compare product performance through videos posted by experienced consumers. User generated content is accessible for everyone, including in marketers who can monitor the consumers responses to their products. They can evaluate their products by seeing vloggers (or consumers) comments and measure their products. User generated content works as an online seller's free assistant to help consumers identify products that best match their needs (Chen \& Xie, 2008). Viewers can give ratings, likes or share the experience, while others can evaluate the alternative in order to make a purchasing decision. 
A willingness to participate is significantly affected by brand attachment and consumer generated advertisement (CGA) attitudes, whereas monetary rewards do not significantly influence a willingness to participate and negatively affect future behavioral intentions (Shulga et. al., 2018). They also found that CGA attitudes and willingness to participate mediate the relationship between brand attachment and brand loyalty. Brand attachment in combination with positive CGA attitudes greatly outweigh monetary rewards.

Most content creators on YouTube, particularly beauty vloggers, should pay attention to their subscribers and total viewers. They compete with each other to attract viewers because more viewers means they are paid more for their content. Companies whose products are reviewed by online bloggers do not pay fees to the content creators making it an extremely cost efficient method of advertisement. The content creators merely share their experiences through an audio visual media to convey the value of the products to others (Hesmondhalgh, 2010).

Shulga et. al. (2018) suggests that companies should actively engage in value co-creation, specifically in CGA co-creation with their brand communities and devoted customer-base to strengthen their brand, improve brand loyalty and future behavioral intentions. YouTube focuses on the "periphery" of what has long been held as the center of attention - the television show or the film - and positions it to play a key role in helping to construct meaning, communities of interest, and the framework of evaluation which are important to the cultural experience (Snickars \& Vonderau, 2009).

\subsection{Purchase Intention}

Intention can be defined as "a person's motivation in relation to his awareness of planning to exert effort to behave (Eagly \& Chaiken, in Wang, 2015). Purchase intention reflects a conscious plan in the effort to purchase a certain brand (Spears \& Singh, in Wang, 2015). Individual characteristics and environmental characteristics are two important factors that influence clothing purchase decisions (Kwan, in Wang, 2015). According to Jalalkamali and Nikbin (in Wang, 2015), in a complex business environment, consumers usually make purchase decisions based on price, quality, product brands, advertisements, friends and family recommendations and previous buying experience. The internet provides many choices for consumers to exchange opinions. Online consumer reviews, especially professional reviews, can significantly influence the interests of one's purchases (Zhu \& Zhang, 2010).

The measurement of purchase intentions has often been used to identify niche markets and potential for product innovation. Although it cannot be guarantee that consumers will act on their intentions, there are some factors we can control or at least have the knowledge that will influence the predictive accuracy of consumer intentions (Ferraz et. al., 2017).

\subsection{Attitude}

Marketers must focus on delivering content with complexity. Content must be useful, easy to use, delivered with quality and quantity. UGC is used as an alternative medium to display information on the product page, instead of only text and product information (Milhinhos, 2015). Fox et. al. (2018) found that narcissism has a positive effect on millennial attitudes toward and intention in selfie-marketing on visual content-sharing apps. The results also demonstrate that millennials seek to use selfies to present their selfconcepts differently in various visual content-sharing environments.

Quality of information refers to the usefulness of the available information in aiding a decision maker to evaluate his/her true utility associated with an alternative product (Keller \& Staelin, 1987). Quality consists of two dimensions: usefulness of content and completeness of information (Yang et. al., 2005). Usefulness refers to the relevance, accuracy, benefit and timeliness of the information provided. A consumer's perceptions of the usefulness of information are strongly related with the quality of the information (Keller \& Staelin, 1987). Meanwhile, completeness refers to whether information is perceived to be comprehensive and complete (Liu et. al., 2000). 
The effect of attitude toward behavior and subjective norms on intentions are moderated by the perception of behavioral control. People are expected to carry out their intentions when the opportunity arises (Ajzen, 2019). There are several key concepts in Psychology and Marketing that are essential to understand consumer behavior. They include: memory and cognition, affect and emotions, judgment and decisionmaking, group dynamics and attitudes (Ajzen, 2008).

Attitude is an important concept in research on advertising and marketing because it is considered stable and tends to predict consumer behavior (Mitchell \& Olson, 1981). Perloff (in Wang, 2015) defines attitude as a learning, broad evaluation of an object (person, place or problem) that affects thinking and action. Schifman and Kanuk (2008) state that attitudes are expressions of feeling (inner feeling) that reflect whether someone is happy or unhappy, likes or dislikes, agrees or disagrees with an object. Fishbein and Ajzen (1977) define attitude as a combination of cognition (i.e. trust) and affection (i.e. evaluation). Affective and cognitive components are very important and relate to feelings, beliefs and evaluations of a product by consumers, whilst an interest in behaviour is related to the final actions of consumers (Daughtery et. al., 2008). Attitudes can shape perceptions, influence judgment and predict behavior (Perloff, in Wang, 2015).

A pleasant attitude will create buying interest, and consumer attitudes can change rapidly depending on behavior, motivation, demographics, reference group, satisfaction or dissatisfaction, purchase scenario, sales environment, product innovation and technological progress (Bahtar \& Muda, 2016). A positive attitude has a positive effect on interest in behavior (Mosavi \& Ghaedi, in Wang, 2015). Attitudes also play an important role in predicting consumer behavior.

\subsection{Perceived Credibility}

Credibility consists of expertise and trust. Ohanian (1989) defines credibility as a positive characteristic of communicators who can influence the recipient's support for certain information and are willing to provide true information to other users (Racherla \& Friske, in Bahtar and Muda, 2016). Credibility is used to assess the quality of information (Bae \& Lee, 2011). Credibility can be defined as "the attitude towards a source of communication obtained by the recipient of information" (Wang, 2015). Credibility is the perception of a number of viewers on the quality of communicators or informants (Wang, 2015).

A person will tend to accept recommendations from credible communicators (trustworthy) because they have similar opinions to their own personal values and attitudes (Perloff, in Wang, 2015). Hung et. al. (2011) demonstrate that audience communication and interaction with other users will trigger high interpersonal trust. If a vlogger has high credibility, they will become popular on YouTube. The popularity of a vlogger will attract more viewers to watch, leave comments, rank, like videos and subscribe to the vlogger's channel (Mir \& Rehman, 2013). Credibility of the source of information is important if the consumer is to trust their opinion.

Previous research also shows that in a trusted internet environment, users are willing to seek more information and feel safe and comfortable in responding to open information (Hung et. al., 2011). Jonas (2010) found that teenagers in the Philippines like UGC such as bloggers, video creators and those who contribute to online review forums who are considered more credible than company-generated content (PGC), even though they personally do not know and do not have a relationship with these users.

Mir and Rehman (2013) examine the factors that influence consumer attitudes towards UGC, concluding that perceived credibility had a positive effect on the attitude of YouTube users. However, nowadays, consumers are smarter because they place greater emphasis on the content creator's credibility. This shows that a messenger or advertisement does not have to be famous, but they must have a high level of credibility. The product advertisements that are delivered should be compatible with the messenger and the messenger must have sufficient knowledge about the product. 


\subsection{User Activity}

Haridakis and Hanson (2009) explain that interpersonal interactions on YouTube are shaped by social and psychological characteristics. Yeo (2010) explains that in the relationship between the personality of YouTube users and the use of YouTube, openness and extraversion (a person's comfort in interacting with others) are positively related to high user activity. Someone who judges himself with the characteristics of high openness tends to consider the use of YouTube videos as an active search rather than purely entertainment (Yeo, 2010).

Tidwell and Walther (2002) extend the strategies from Face-to-Face (FtF) communication to computermediated communication (CMC). They argue that these three strategies can be applied to CMC, but their availability is limited according to CMC arrangements. For example, active and passive strategies require public arrangements to be seen by the target or by asking questions from third parties (Tidwell \& Walther, 2002)

\subsection{Reference Groups and Opinion Leaders}

Consumers often look for guidance and approval from others before making a purchase decision (Flynn et. al., 1996). Obtaining opinions from others will reduce the amount research and evaluation required by a consumer and eliminates the risk of uncertainty. Consumers interact socially with a reference group and are influenced by opinion leaders or family members before making a purchase decision (Lam et. al., 2011). Consumers use reference group such as beauty vloggers to seek opinions and experience about the products performance, e.g.: the texture, smell, color, the quality, price, where the store is and more. They then compare that content with other content from other vloggers reviewing the same product to make purchase decisions. Consumers actively seek opinions from anyone, including opinion leaders, family members and/ or friends to make purchase decisions that satisfy their needs of information and reduce the risk of choosing the wrong product.

Opinion leaders are someone who is more aware and knowledgeable about a market and its products than others and is often the first one to try new products (Lamb, et. al., 2011). Well known beauty vloggers, or those who have a large number of subscribers often get opportunities to try new products from a firm, who send products to the content creators to encourage them to post content relating to their product. While Valente \& Pumpuang (2007) define opinion leaders as someone who influences the opinions, attitudes, beliefs, motivations, and behaviors of others. Opinion leaders can influence potential consumers by increasing awareness, persuading them to try the product, and convincing others to purchase. Opinion leaders are often recognized as opinion leaders who have a large number of subscribers or followers.

\section{Methodology}

\subsection{Data and Sample}

\subsection{Description of Variables}

The questionnaire was distributed online through a Google form. Responses from 200 samples were obtained from respondents with a minimum age of 18 years old who have watched at least 1 beauty product review video on YouTube. The respondents were asked to complete a questionnaire containing statements about attitudes towards UGC, perceived credibility, activity on UGC and beauty product purchase intention replicative to Wang (2015). Attitudes toward UGC on YouTube will measure how useful or useless, important or insignificant, pleasant or unpleasant and good or not UGC beauty product content on YouTube really is. Perceived Credibility is measured by the perceptions of UGC beauty products on YouTube and the affect this has on the quality of the UGC uploader. Statements are provided with a multi-choice answer using 
a Likert scale with a score between 1 (strongly disagree) and 5 (strongly agree). Users Activity is measured by how often users watch, search, like or comment, subscribe and upload UGC content on beauty products on YouTube. Purchase Intention is measured by statements reflected in transactional and preferential intentions. The regression model proposed is:

$$
\mathrm{PI}=\beta_{0}+\beta_{1} \mathrm{Au}+\beta_{2} \mathrm{PC}+\beta_{3} \mathrm{UA}+\mathrm{e}
$$

Where PI is Purchase Intention, Au is Attitude Towards UGC, PC is Perceived Credibility and UA is User Activities.

\section{Results and Discussion}

The questionnaires were distributed online through a Google form. The respondents' profiles are reflected in the following table.

Table 2. Respondents' Profiles

\begin{tabular}{ccccccccc}
\hline \multirow{2}{*}{ Gender } & \multicolumn{2}{c}{ Marital Status } & \multicolumn{3}{c}{ Age (years old) } & \multicolumn{3}{c}{ Education } \\
& Single & Married & $18-30$ & $31-40$ & $41-50$ & $\begin{array}{c}\text { High } \\
\text { School }\end{array}$ & $\begin{array}{c}\text { Under } \\
\text { Graduate }\end{array}$ & $\begin{array}{c}\text { Graduate\&Post } \\
\text { Graduate }\end{array}$ \\
\hline Male & 11 & 3 & 9 & 3 & 2 & 5 & 6 & 3 \\
Female & 120 & 66 & 154 & 26 & 6 & 58 & 106 & 22 \\
Total & 131 & 69 & 163 & 29 & 8 & 63 & 112 & 25 \\
Percentage & $65,5 \%$ & $34,5 \%$ & $81.5 \%$ & $14.5 \%$ & $4 \%$ & $31.5 \%$ & $56 \%$ & $12.5 \%$ \\
\hline
\end{tabular}

The majority of the respondents were female, aged between 18-30 years old and are undergraduates. The responses to the 4 variables tested can be seen in the table below.

Table 3. Responses for "Attitude" Variable

\begin{tabular}{|c|c|c|c|c|c|c|c|c|c|c|}
\hline \multirow[t]{2}{*}{ Statements } & \multicolumn{8}{|c|}{ Strongly } & \multicolumn{2}{|c|}{$\begin{array}{l}\text { Strongly } \\
\text { Agree }\end{array}$} \\
\hline & $\mathrm{F}$ & $\%$ & $\mathrm{~F}$ & $\%$ & $\mathrm{~F}$ & $\%$ & $\mathrm{~F}$ & $\%$ & $\mathrm{~F}$ & $\%$ \\
\hline UGC is very useful & 1 & $0.5 \%$ & 1 & $0.5 \%$ & 29 & $14.5 \%$ & 79 & $39.5 \%$ & 90 & $45.0 \%$ \\
\hline UGC is very important & 2 & $1.0 \%$ & 6 & $3.0 \%$ & 44 & $22.0 \%$ & 78 & $39.0 \%$ & 70 & $35.0 \%$ \\
\hline UGC is very fun & 0 & $0.0 \%$ & 6 & $3.0 \%$ & 48 & $24.0 \%$ & 72 & $36.0 \%$ & 74 & $37.0 \%$ \\
\hline UGC is very good and attractive & 0 & $0.0 \%$ & 7 & $3.5 \%$ & 62 & $31.0 \%$ & 76 & $38.0 \%$ & 55 & $27.5 \%$ \\
\hline
\end{tabular}

It is seen in Table 3 that the majority of respondents consider that the review of beauty products presented on YouTube is very useful, important, fun and very good.

Table 4. Responses for "Perceived Credibility" Variable

\begin{tabular}{|c|c|c|c|c|c|c|c|c|c|c|}
\hline \multirow[t]{2}{*}{ Statements } & \multicolumn{4}{|c|}{ Strongly } & \multicolumn{2}{|c|}{ Neutral } & \multicolumn{2}{|c|}{ Agree } & \multicolumn{2}{|c|}{$\begin{array}{l}\text { Strongly } \\
\text { Agree }\end{array}$} \\
\hline & $\mathrm{F}$ & $\%$ & $\mathrm{~F}$ & $\%$ & $\mathrm{~F}$ & $\%$ & $\mathrm{~F}$ & $\%$ & $\mathrm{~F}$ & $\%$ \\
\hline $\begin{array}{l}\text { UGC of beauty product on } \\
\text { YouTube is unbiased }\end{array}$ & 5 & $2.5 \%$ & 21 & $10.5 \%$ & 109 & $54.5 \%$ & 53 & $26.5 \%$ & 12 & $6.0 \%$ \\
\hline $\begin{array}{l}\text { UGC of beauty product on } \\
\text { YouTube is credible }\end{array}$ & 3 & $1.5 \%$ & 12 & $6.0 \%$ & 91 & $45.5 \%$ & 72 & $36.0 \%$ & 22 & $11.0 \%$ \\
\hline $\begin{array}{l}\text { UGC of beauty product on } \\
\text { YouTube is reliable }\end{array}$ & 2 & $1.0 \%$ & 12 & $6.0 \%$ & 80 & $40.0 \%$ & 79 & $39.5 \%$ & 27 & $13.5 \%$ \\
\hline
\end{tabular}




\begin{tabular}{c|cccccccccc}
$\begin{array}{c}\text { UGC of beauty product on } \\
\text { YouTube tells the truth }\end{array}$ & 3 & $1.5 \%$ & 18 & $9.0 \%$ & 107 & $53.5 \%$ & 50 & $25.0 \%$ & 22 & $11.0 \%$ \\
\hline
\end{tabular}

Table 4 shows that the majority of the respondents rated UGC content regarding beauty product reviews on YouTube to be unbiased, credible, reliable and truthful. The following table is the recapitulation of respondents regarding the "user activities" variable.

Table 5. Responses for "User Activities" Variable

\begin{tabular}{ccccccccccc}
\hline Statements & \multicolumn{2}{c}{ Never } & \multicolumn{2}{c}{ Seldom } & \multicolumn{2}{c}{ Sometimes } & \multicolumn{2}{c}{ Often } & \multicolumn{2}{c}{ Always } \\
& $\mathrm{F}$ & $\%$ & $\mathrm{~F}$ & $\%$ & $\mathrm{~F}$ & $\%$ & $\mathrm{~F}$ & $\%$ & $\mathrm{~F}$ & $\%$ \\
\hline $\begin{array}{c}\text { How often do you watch beauty } \\
\text { product UGC on YouTube? }\end{array}$ & 0 & $0.0 \%$ & 27 & $13.5 \%$ & 99 & $49.5 \%$ & 62 & $31.0 \%$ & 12 & $6.0 \%$ \\
$\begin{array}{c}\text { How often do you search for beauty } \\
\text { product Contents on YouTube? }\end{array}$ & 5 & $2.5 \%$ & 46 & $23.0 \%$ & 84 & $42.0 \%$ & 52 & $26.0 \%$ & 13 & $6.5 \%$ \\
$\begin{array}{c}\text { How often do you liking beauty } \\
\text { product UGC on YouTube? }\end{array}$ & 37 & $18.5 \%$ & 51 & $25.5 \%$ & 82 & $41.0 \%$ & 23 & $11.5 \%$ & 7 & $3.5 \%$ \\
$\begin{array}{c}\text { How often do you comment on beauty } \\
\text { product UGC on YouTube? }\end{array}$ & 113 & $56.5 \%$ & 50 & $25.0 \%$ & 33 & $16.5 \%$ & 0 & $0.0 \%$ & 4 & $2.0 \%$ \\
$\begin{array}{c}\text { How often do you subscribe on beauty } \\
\text { product UGC on YouTube }\end{array}$ & 75 & $37.5 \%$ & 50 & $25.0 \%$ & 47 & $23.5 \%$ & 27 & $13.5 \%$ & 1 & $0.5 \%$ \\
$\begin{array}{c}\text { I have been upload beauty products } \\
\text { video (s) on YouTube }\end{array}$ & 168 & $84.0 \%$ & 16 & $8.0 \%$ & 13 & $6.5 \%$ & 3 & $1.5 \%$ & 0 & $0.0 \%$ \\
\hline
\end{tabular}

The majority of the respondents watch and search for UGC on YouTube. The responses for the purchase intention variable are shown below.

Table 6. Responses for "Purchase Intention" Variable

\begin{tabular}{|c|c|c|c|c|c|c|c|c|c|c|}
\hline \multirow{2}{*}{ Statements } & \multicolumn{4}{|c|}{ Strongly } & \multicolumn{2}{|c|}{ Neutral } & \multicolumn{2}{|c|}{ Agree } & \multicolumn{2}{|c|}{$\begin{array}{l}\text { Strongly } \\
\text { Agree }\end{array}$} \\
\hline & $\mathrm{F}$ & $\%$ & $\mathrm{~F}$ & $\%$ & $\mathrm{~F}$ & $\%$ & $\mathrm{~F}$ & $\%$ & $\mathrm{~F}$ & $\%$ \\
\hline $\begin{array}{l}\text { I intend to buy the product recommended } \\
\text { by UGC on YouTube }\end{array}$ & 4 & $2.0 \%$ & 23 & $11.5 \%$ & 88 & $44 \%$ & 58 & $29 \%$ & 27 & $13.5 \%$ \\
\hline $\begin{array}{l}\text { I will but the product recommended by } \\
\text { UGC on YouTube in the near future } \\
\text { It is very likely I will buy products }\end{array}$ & 10 & $5.0 \%$ & 33 & $16.5 \%$ & 102 & $51 \%$ & 42 & $21 \%$ & 13 & $6.5 \%$ \\
\hline $\begin{array}{l}\text { reviewed by UGC on YouTube in the near } \\
\text { future }\end{array}$ & 7 & $3.5 \%$ & 30 & $15.0 \%$ & 98 & $49 \%$ & 48 & $24 \%$ & 17 & $8.5 \%$ \\
\hline
\end{tabular}

The majority of respondents intend to buy beauty products that are reviewed in UGC on YouTube, and they agree to buy beauty products that are reviewed on YouTube content in the near future. The respondents also state that they are very likely to buy beauty products that are reviewed on YouTube in the near future, which means they have a strong belief in buying these beauty products. 
Firda Nosita, Tina Lestari

Table 7. Regression Model

\begin{tabular}{cccc}
\hline & Coef & T & Sig \\
\hline $\mathrm{C}$ & -0.341 & -0.392 & 0.695 \\
$\mathrm{Au}$ & 0.191 & 3.192 & 0.002 \\
$\mathrm{PC}$ & 0.462 & 7.496 & 0.000 \\
$\mathrm{UA}$ & 0.042 & 1.031 & 0.304 \\
$\mathrm{R} 2$ & 0,432 & & \\
\hline
\end{tabular}

Table 7 shows that attitudes have an affect on purchase intention in beauty products that are reviewed in UGC content on YouTube. Shao (2009) found that the purpose of someone watching UGC is to obtain information, as entertainment and for mood management. The more attractive the content presented by UGC on YouTube is, the more it is considered as useful, important, fun and very good, which is necessarily to attract the viewers. Authenticity is a crucial factor considered by viewers. Beauty bloggers usually have a specialization in the type of content they create. For example, they can specialize their content on drugstore beauty products or high-end products. this enables the viewers to easily search for the content they desire.

YouTube users may be interested in watching UGC content for beauty products to improve their beauty skills. Tutorials or reviews of beauty products often show how to use beauty products to maximize the use of the product. In some cases, content creators provide tips and advice to viewers on how to use the beauty products they review and are often seen as experts in beauty.

Affective and cognitive attitude is crucial, and is related to feelings, beliefs and evaluation of a product, while behavior intention is related to the final action by a customer (Daugherty et. al., 2008). Positive attitudes towards UGC will increase user's purchase intention (Daughtery et. al., 2015). Wang (2014) suggests that positive online consumer reviews with benefit-centric information has the greatest positive effect on consumer's product attitudes and purchase intentions. Videonitch shows that approximately $20 \%$ of users that watch videos on YouTube tend to leave the videos within the first 10 seconds if the videos are unattractive (Flahive, 2017). This demonstrates the importance of the design of the content.

The results of this study are consistent with several previous studies i.e. perceptions of credibility have an effect on buying interest. Credible information will influence the audience's assessment of the content uploaded by a vlogger that also affects the traffic to their channel. Mir and Rehman (2013) examine the factors that influence consumer's attitudes towards UGC, and conclude that perceptions of credibility have a positive effect on the attitudes of YouTube users towards UGC. Interpersonal influences play an important role in purchasing cosmetics, because most cosmetic advertisements fail to provide reliable information because of the use of excessive estimation effects (Hung et. al., 2011).

Message sources that have high credibility have a positive influence on consumer attitudes towards a brand (Erdogan, 1999). Several factors can affect the credibility of the message, such as media messages, expertise, knowledge and credibility of the source. Internet users consider that information on the web is more credible than traditional media such as newspapers (Wathen \& Burkell, in Mir \& Rehman, 2013). A credible person is a trusted person. Perceptions about source credibility influence message evaluation, behavioral attitudes and interests (Ohanian, 1989). Credibility is also related to the expertise possessed by content providers. Beauty vloggers who are "recognized" as having expertise in the use of beauty products are considered to provide objective opinions based on their experience. Credibility is generally supported by expertise and experience. For example, beauty vloggers who have good knowledge of the content, textures, brands, and other information related to products are able to enhance the knowledge of their viewers. Beauty vloggers who have extensive experience will be seen as a more trusted person compared to a new beauty vlogger who does not have much experience.

UGC content allows viewers to see and read other people's opinions (through the comments column) to minimize risks and obtain information before making a purchase. Users who create product content or 
information on social media are seen as "opinion leaders" by other users (Cheong \& Morrison, in Mir \& Rehman, 2013).

Based on a survey conducted by MarkPlus Inc. and ZAP Clinic, female consumers in Indonesia will almost always view online product reviews before purchasing a beauty product (Bella, 2008). Further, 55\% of women use Instagram and $41.6 \%$ use YouTube to view product information. In addition, $40.9 \%$ of female consumers claim to trust the information provided by beauty bloggers more than that provided by their friends $(38.1 \%)$.

The third finding shows that user activity at UGC on YouTube does not affect purchase intentions. Vlogger helps beauty product marketers provide makeup tutorials on how to use beauty products correctly. Approximately $97 \%$ of conversations about beauty products on YouTube occur on the official channel of beauty vloggers or content creators. Beauty vloggers create a tutorial video to provide tips and tricks on how to use the product, and provide recommendations on which products to buy according to the customer's skin type, budget and the intended event. These objectives cannot be achieved by marketers through commercial advertisements with limited time. The content created by beauty vloggers is therefore considered more authentic. Shao (2009) found that the purpose of UGC users is to engage with other users to enrich their social relationships and to create a virtual community.

The "Guardian" Journalist found that, in an online group containing 100 people, only 1 will create the content, 10 people will interact with the content (comment or complement), and the remaining 89 people will watch the content (Arthur, in Dijck, 2008).

\section{Conclusion}

The results of this study prove that UGC content affects purchase intentions. The use of advanced video creation tools is important to increase the attractiveness of a video and to attract more viewers (or potential customers). Sophisticated tools enable content creators to optimize their videos with visual effects to further attract their viewers. The first impression of a video is important to viewers and will determine whether or not they watch the entire video.

Purchase intentions are influenced by the credibility of the informant or the UGC creator. UGC video creators must be trustworthy, and they must have experience and expertise in the product they are reviewing. Their creditworthiness increases if they are able to provide tips or tricks that can improve the experience of their viewers. User activities such as searching, liking, commenting, or subscribing are considered as parasocial forms of interaction. Content creators and viewers of the content need to engage with each other and often form social communities in order to exchange information.

For marketers (companies), the phenomenon of UGC content can be utilized by embracing UGC content makers who are considered credible. Marketers and companies are able to identify how many followers a particular content creator has to determine the level of trustworthiness that content creator has in the market. In addition, marketers can provide training or provide facilities for UGC content creators, for example, by holding a beauty class for them to increase their knowledge and understanding in order to increase audience knowledge and understanding.

Companies and marketers should continuously improve the quality of their products, because the credibility of creators is dependent on their experience with the product. Content creators must be honest in evaluating a product to be trusted by the audience. YouGov (2016) found that $90 \%$ of Indonesians prioritize product quality over the price of a product when making a purchasing decision. This proves that the people of Indonesia today are more aware of product quality. Marketers can also monitor discussions in beauty product review communities to determine the level of interest in their products. In addition, marketers can also identify any shortcomings of their products and competitors by looking at comments or discussions on YouTube beauty vloggers channels. In doing so, the companies can assess how "successful" their product is and how attractive their products are to consumers. 
Future research may analyze whether UGC has an affect on purchase decisions or whether UGC is the dominant reference for consumers before making a purchase decision. Therefore, future research could also introduce new independent variables to provide a deeper analysis of customer behaviors.

\section{References}

Ajzen, I. (2008). Consumer attitudes and behavior. Handbook of consumer psychology, 1, 525-548. https://www.researchgate.net/profile/Icek_Ajzen/publication/264000611_Consumer_attitudes_and_behavior/links/0a85 e53c7d49b08fb6000000.pdf

Ajzen, Icek, \& Fishbein, M. (2013). The Influence of Attitudes on Behavior. Journal of Chemical Information and Modeling, 53(9), 1689-1699. https://doi.org/10.1017/CBO9781107415324.004

APJII. (2018). Penetrasi \& Profil Perilaku Pengguna Internet Indonesia. Apjii. Retrieved from www.apjii.or.id

Bae, S., \& Lee, T. (2011). Product type and consumers' perception of online consumer reviews. Electronic Markets, 21(4), 255-266. https://doi.org/10.1007/s12525-011-0072-0

Bahtar, A. Z., \& Muda, M. (2016). The impact of User-Generated Content (UGC) on product reviews towards online purchasing-A conceptual framework. Procedia Economics and Finance, 37, 337-342. https://doi.org/10.1016/s22125671(16)30134-4

Bella, A. (2018, August 16). Retrieved from marketeers.com: http://marketeers.com/seperti-apa-perilaku-konsumenkecantikan-indonesia/

Chen, Y., \& Xie, J. (2008). Online consumer review: Word-of-mouth as a new element of marketing communication mix. Management science, 54(3), 477-491. https://doi.org/10.1287/mnsc. 1070.0810

Chrisbiyanto, A. (2017, August 1). Retrieved from ekbis.sindonews: https://ekbis.sindonews.com/read/1225856/34/pasar-kosmetik-indonesia-10-besar-dunia-1501531391

Christodoulides, G., Jevons, C., \& Bonhomme, J. (2012). Memo to marketers: Quantitative evidence for change: How user-generated content really affects brands. Journal of advertising research, 52(1), 53-64. https://doi.org/10.2501/JAR52-1-000-000

Daugherty, T., Eastin, M. S., \& Bright, L. (2008). Exploring consumer motivations for creating user-generated content. Journal of interactive advertising, 8(2), 16-25. https://doi.org/10.1016/S0301-2115(96)02613-9

Erdogan, B. Z. (1999). Celebrity endorsement: A literature review. Journal of marketing management, 15(4), 291-314. https://doi.org/10.1362/026725799784870379

Ferraz, S. B., Buhamra, C., Laroche, M., \& Veloso, A. R. (2017). Green products: A cross-cultural study of attitude, intention and purchase behavior. RAM. Revista de Administração Mackenzie, 18(5), 12-38. https://doi.org/10.1590/1678-69712017/administracao.v18n5p12-38

Flahive, E. (2017, December 13). Retrieved from videonitch.com: http://videonitch.com/2017/12/13/36-mind-blowingyoutube-facts-figures-statistics-2017-re-post/

Fox, A. K., Bacile, T. J., Nakhata, C., \& Weible, A. (2018). Selfie-marketing: exploring narcissism and self-concept in visual user-generated content on social media. Journal of Consumer Marketing, 35(1), 11-21. https://doi.org/10.1108/JCM-03-2016-1752

Hagander, A., \& Rúnarsdóttir, M. (2016). The Online Consumer Decision Journey in the Cosmetic Industry. http://lup.lub.lu.se/student-papers/record/8887123/file/8887125.pdf

Haridakis, P., \& Hanson, G. (2009). Social interaction and co-viewing with YouTube: Blending mass communication reception and social connection. Journal of Broadcasting \& Electronic Media, 53(2), 317-335. https://doi.org/10.1080/08838150902908270

Hennig-Thurau, T., Gwinner, K. P., Walsh, G., \& Gremler, D. D. (2004). Electronic word-of-mouth via consumeropinion platforms: what motivates consumers to articulate themselves on the internet?. Journal of interactive marketing, 18(1), 38-52. https://doi.org/10.1002/dir.10073

Hesmondhalgh, D. (2010). User-generated content, free labour and the cultural industries. ephemera, 10(3/4), 267-284. https://doi.org/10.4337/9781781008003.00026

Hung, K., Li, S. Y., \& Tse, D. K. (2011). Interpersonal trust and platform credibility in a Chinese multibrand online community. Journal of Advertising, 40(3), 99-112. https://doi.org/10.2753/JOA0091-3367400308

Johnson, T. J., \& Kaye, B. K. (2004). Wag the blog: How reliance on traditional media and the Internet influence credibility perceptions of weblogs among blog users. Journalism \& Mass Communication Quarterly, 81(3), 622-642. https://doi.org/10.1177/107769900408100310 
Jonas, J. R. O. (2010). Source credibility of company-produced and user-generated content on the internet: An exploratory study on the Filipino youth. Philippine Management Review, 17. https://www.tmc.upd.edu.ph/index.php/pmr/article/view/1927

Keller, K. L., \& Staelin, R. (1987). Effects of quality and quantity of information on decision effectiveness. Journal of consumer research, 14(2), 200-213. https://doi.org/10.1086/209106

Liu, C., Arnett, K. P., \& Litecky, C. (2000). Design quality of websites for electronic commerce: Fortune 1000 webmasters' evaluations. Electronic Markets, 10(2), 120-129. https://doi.org/10.1080/10196780050138173

Milhinhos, P. R. V. (2015). The impact of content marketing on attitudes and purchase intentions of online shoppers: the case videos \& tutorials and user-generated content (Doctoral dissertation). https://bibliotecadigital.fgv.br/dspace/handle/10438/16054

Mir, I. A., \& Ur REHMAN, K. (2013). Factors affecting consumer attitudes and intentions toward user-generated product content on YouTube. Management \& Marketing, 8(4). Retrieved from http://search.proquest.com.ezproxy.library.uq.edu.au/docview/1503088220?pq-origsite=summon

Mitchell, A. A., \& Olson, J. C. (1981). Are product attribute beliefs the only mediator of advertising effects on brand attitude?. Journal of marketing research, 18(3), 318-332. https://doi.org/10.1177/002224378101800306

Ohanian, R. (1990). Construction and validation of a scale to measure celebrity endorsers' perceived expertise, trustworthiness, and attractiveness. Journal of advertising, 19(3), 39-52. https://doi.org/10.1080/00913367.1990.10673191

Paquette, H. (2013). Social media as a marketing tool: a literature review. https://doi.org/10.4018/978-1-5225-60647.ch011

Shao, G. (2009). Understanding the appeal of user-generated media: a uses and gratification perspective. Internet research, 19(1), 7-25. https://doi.org/10.1108/10662240910927795

Shulga, L. V., Busser, J. A., \& Bai, B. (2018). Factors affecting willingness to participate in consumer generated advertisement. International Journal of Hospitality Management, 74, 214-223. https://doi.org/10.1016/j.ijhm.2018.05.004

Snickars, P., \& Vonderau, P. (2009). The YouTube Reader. In Lnblt (Vol. 12). https://doi.org/papers3://publication/uuid/09683C4F-398D-45A2-BFAF-26E62450270A

Tidwell, L. C., \& Walther, J. B. (2002). Computer-mediated communication effects on disclosure, impressions, and interpersonal evaluations: Getting to know one another a bit at a time. Human communication research, 28(3), 317348.https://doi.org/10.1093/hcr/28.3.317

Van Dijck, J. (2009). Users like you? Theorizing agency in user-generated content. Media, culture \& society, 31(1), 4158.https://doi.org/10.1177/0163443708098245

Valente, T. W., \& Pumpuang, P. (2007). Identifying opinion leaders to promote behavior change. Health Education \& Behavior, 34(6), 881-896. https://doi.org/10.1177/1090198106297855

Verhellen, Y., Dens, N., \& De Pelsmacker, P. (2013). Consumer responses to brands placed in Youtube movies: the effect of prominence and celebrity endorser expertise. Journal of electronic commerce research. -Long Beach, Calif., 14(4), 287-303.

Wang, C. (2015). Do People Purchase What They Viewed from Youtube? https://diginole.lib.fsu.edu/islandora/object/fsu\%3A253059/

We Are Social \& Hootsuite. (2019). Digital 2019. In We Are Social \& Hootsuite. Retrieved from https://es.slideshare.net/DataReportal/digital-2019-argentina-january-2019-v01?from_action=save

Yang, Z., Cai, S., Zhou, Z., \& Zhou, N. (2005). Development and validation of an instrument to measure user perceived service quality of information presenting web portals. Information \& management, 42(4), 575-589. https://doi.org/10.1016/j.im.2013.03.001

Yeo, T. D. (2010, May). Modeling personality influences on youtube usage. In Fourth International AAAI Conference on Weblogs and Social Media. 